\title{
Резюмета от Първи национален симпозиум по обструктивна сънна апнея и хъркане с международно участие
}

\author{
Some Medico-anthropological Results from Varna Chalcolithic Necropolis Study \\ Georgi Marinov \\ Medical University of Varna
}

\begin{abstract}
The discovery of Varna chalcolithic necropolis on October 2, 1972 belongs to the most significant discoveries of archaeology that led to re-evaluation of the conception dominating at that time arguing that Europe and its south-eastern part, the Balkan peninsula is one of 'deaf outlying areas of ancient civilized world'. The study of the necropolis proved that in the middle of the fifth millennium B.C. the inhabitants of the North-Western Black Sea Coast created a highly developed and world-famous culture, the so-called 'Late eneolithic culture of Varna'. Under the guidance of Ivan Ivanov, research fellow of archaeology, 300 graves were revealed in $7500 \mathrm{~m}^{2}$ within the necropolis. The expert evaluation performed together with correspondingmember prof. Y. Yordanov established human remains in 255 graves while there were no remains in the rest 45 ones ('symbolic' or kenotaphes'). Skeleton position in the grave was either stretched, or bent. Biological reconstruction of population revealed that the graves of persons deceased at a comparatively young age from a contemporary viewpoint prevailed. Most deceased males were aged between 25 and 35 years while most deceased females did between 20 and 30 years. Age limit for males was 40-45 years and that one for females was 30-35 years. There are much less persons younger than 18 years as three infants were aged 4-6, 6, and 8 months only. There were no graves of children aged between 2 and 7 years. Both inspection and anthropometric examinations of the best preserved cranium from grave No 43 performed by corresponding-member prof. Y. Yordanov demonstrated that it was of European-like nature and could be assigned to the dinaric-nordic variation of dinaric race type thus confirming the opinion about the local Balkanic origin of the deceased person. Based on this cranium, corresponding-member prof. Y. Yordanov carried out a portrait reconstruction of the head after prof. Gerasimov's method. The odontometric examinations of 98 teeth of permanent dentition demonstrated similarity with the teeth of other European people and this dentition seemed analogous to that of contemporary people and presented with the largest size of first mollars. The dimensions of mandibulae and teeth from the necropolis showed a process of cranial gracilization predominantly in the facial part. There was a different extent of tooth erosion. In some graves, special golden applications inserted in the labial region were detected which were identical to similar ones located on the masks. The size of the long bones was not very large, however, the osseous relief was strongly expressed. Mean male height was $167 \mathrm{~cm}$ but mean female one was $159 \mathrm{~cm}$. In grave No 63 among the graves with unnatural bone position, there was a skeleton of a male (?) aged between 30-35 years (?) which bones were broken and irregularly located one to another. The cranium was broken into more than fifteen fragments. The bones presented with alterations due to a systemic osseous disease, inflicted, most probably, buy irritation of the frontal and temporal cerebral lobes. There was a sequestration of a small mandibular region along with massive osteoarthrosis of the left upper talocrural joint. The expert evaluation proved that it dealt either with a grave opened after soft tissue decay, or with a repeated funeral of bones rather than of a cadaver. A skeleton with scoliosis was detected, too.
\end{abstract}




\title{
Някои медико-антропологични резултати от проучването на Варненския халколитен некропол
}

\author{
Георги Маринов
}

Медицински университет, Варна

Резюме: Откриването на Варненския халколитен некропол (02.10.1972 г.) се отнася към най-значимите открития на археологията, довело до преоценка на господстващата по това време концепция, че Европа и нейната югоизточна област, в т.ч. и Балканският полуостров, е „една от глухите покрайнини на древния цивилизован свят“. Неговото проучване доказа, че в средата на петото хилядолетие преди Христа обитателите на Северозападното Черноморие създават високоразвита култура, световноизвестна като „Късноенеолитна култура Варна“. В проучените 7500 м² от некропола, под ръководството на археолога н.с. Иван Иванов са открити 300 гроба. Експертизата на откритите гробове, проведена съвместно с чл. кор. проф. Й. Йорданов, установи човешки останки в 255 гроба, а в 45 гроба такива липсват („символични“ или „кенотафи“). Позицията на скелетите в гроб е в изпънато или в свито положение (,хокер“). Направената биологична реконструкция на популацията установи, че преобладават гробове на починали в сравнително млада от днешна гледна точка възраст. Най-голямата част от погребаните мъже са на 25 - 35 години, а от погребаните жени - на 20 - 30 години. Пределната възраст за мъжете е 40 - 45 години, а за жените - 30 - 35 години. Броят на погребаните под 18 години е сравнително по-малък, а най-младите погребани са 3 деца - на 4-6, на 6 и на 8 месеца. Липсват погребения на деца между 2 и 7 години. Скопичното и метричното изучаване на най-добре запазеният череп от гроб 43 от чл. кор. проф. Й. Йорданов установи, че той е европеиден и може да се отнесе към динаро-нордик вариант на динарския расов тип, което потвърждава становището за местния, балкански произход на погребания. По този череп чл. кор. проф. Й. Йорданов извърши и портретна реконструкция на главата по метода на проф. Герасимов. Одонтометричните данни от проучването на 98 зъба от постоянното съзъбие установи, че те се вместват между данните за другите европейски народи и характеризират съзъбието като такова, каквото е у съвременния човек - с най-големи размери за първите кътници. Размерите на долночелюстните кости и зъбите от некропола показват процес на грацилизация на черепа, изявена предимно в лицевата му част. Отчита се и различна степен на изтриване на зъбите. В част от погребенията се откриха специални златни апликации, които са били поставяни в областта на устните, идентични с подобни разположени и на откритите в некропола маски. Дългите кости имат не много големи размери, но силно изразен костен релеф. Средният ръст на погребаните мъже е 1,67 м, а на жените - 1,59 м. В гроб 63 от гробовете с неестествено положение на костите в тях се откри скелет на около 30 - 35 (?) годишен, мъж (?), костите на който са начупени, в неестествено положение една спрямо друга. Черепът счупен на повече от петнадесет фрагмента. По костите има изменения от системно костно заболяване, които вероятно са предизвиквали дразнене на челните и слепоочните дялове на главния мозьк. Установено е секвестиране на мальк участьк от долната челюст и масивни остеоартрозни изменения в лявата горна скочна става. Експертизата установи, че са касае или за отваряне на гроб след изгниване на меките тъкани, или за препогребение на кости, а не на труп. При един скелет беше установена сколиоза.

\section{Early Short History, Artifacts and CME in SSA}

\section{Pavel Dimov}

Professor and Head ORL Clinic, Trakia University Stara Zagora, Bulgaria e-mail: pddimov@abv.bg

Abstract: Introduction: The present knowledge is beginning from thousand years with daily work of human social communities. 
Objective: To indicate some historical dates and artifacts of SSA (Snoring and Sleep Apnea)

Background: In early history had a relation between old populations in Balkan Peninsula - Trakia and Black Sea Region. At these lands were recovered archeological dates and artifacts of old knowledge and science code especially The Varna Gold with mystic plate and Stara Zagora Neolithic dwellings with gold spiritual Thracian coup.

There were find pre-historic art sculptures plastic clay and small gold pieces with typical characteristic of home with SSA. It is indicate early relationship Stara Zagora and Varna Late Neolithic - Chalcolithic time districts 5-6 mill B.C.

Lasting 20 years there showed CME in ORL and much important events of which form direction of education and training in ENT specialty - 1997 European Academy of Otology and Neuro-Otology (EAONO), 2007 - Lion Foundation for Live surgery transmission; 2009 First meeting of European Academy of Otorhinolaryngology-Head and Neck Surgery (EAORL-HNS) Manheim, Germany which united separate European academies in ENT specialty; European Association of Snoring and Sleep Apnea (EASSA) etc.

Conclusion: The knowledge of the early history will give us clearer information on the development of science

Key words: Old History, Trakia, Balkan Peninsula, Education, Snoring, Sleep Apnea

\title{
Кратка ранна история, артефакти и продължително обучение в ХСА
}

\author{
Павел Димов \\ Началник клиника по УНГ-болести, Тракийски университет - Стара Загора, България \\ e-mail: pddimov@abv.bg
}

Резюме: Въведение: Според настоящем познанията започват от хиляди години в ежедневната работа на човешките социални общности.

Цел: Да се посочат някои исторически данни и артефакти за хъркане и сънна апнея.

Изложение: През ранната човешка история е установена връзка между народите на Балканския полуостров - Тракия и района на Черно море. Посочена е връзка на районите Стара Загора и Варна от ранен неолит и халколит 5-6000 години преди н.е. По тези земи са открити археологични предмети и артефакти на старо знание и научни кодове - Варненското злато с уникална чиния; Старозагорските неолитни жилища и спиритуална златна тракийска купа. Такива праисторически предмети на изкуството, глинени скулптури и малки предмети са отбелязани с типична визуална характеристика на хора с ХСА (хъркане и сънна апнея).

Изложени са важни моменти от последните 20 години ОРЛ история с формираните съвременни основни форми на следдипломна квалификация и сдружения в Европейския съюз, отговорни за обучението и практичните знания на специалистите в оториноларингологията: 1997 г. Европейската академия по отология и невро-отология (EAONO); 2007 г. Лион фондация (Lion Foundation) за транслации с хирургия живо; 2009 г. Първата европейска среща на Европейската академия по оториноларингология, глава-шия хирургия (EAORL-HNS), Манхайм, Германия, обединяваща различните академии; Европейската асоциация по хъркане и сънна апнея (EASSA) и др.

Извод: Познаването на ранната история ще ни даде по-ясна информация за развитието на знанията. Ключови думи: ранна история, Тракия, Балкански полуостров, образование, хъркане и сънна апнея 


\section{Sleep/wake Cycle and Glucose Homeostasis in Humans}

\section{Levent ÖZTÜRK ${ }^{1}$, Gülnur ÖZTÜRK ${ }^{2}$, Oktay KAYA ${ }^{1}$, Elif Ezgi GÜREL ${ }^{1}$}

${ }^{1}$ Department of Physiology, Trakya University Faculty of Medicine, Edirne TURKEY

${ }^{2}$ Department of Physiotherapy and Rehabilitation, Trakya University Faculty of Health Sciences, Edirne TURKEY

Although our knowledge on sleep physiology is rapidly growing and many of the mechanisms generating sleep are elucidated, the function of sleep, in other words, the answer of the question ,why we sleep?" remains its mystery. Human sleep is generally consolidated in a single 7- to 9-h period. Consolidation of the sleep period is probably responsible for the fact that wake-sleep and sleep-wake transitions in man are associated with marked physiological changes. This organization leads to extended period of total fast during nighttime. A major source of ATP is intracellular metabolism of glucose. ATP need by the cells is continuous, whereas glucose support by ingestion is episodic. Thus, blood glucose should be regulated. Sleep onset and the first half of the sleep period are accompanied by a robust increase in plasma glucose, which is followed $10 \mathrm{~min}$ later by a more than $50 \%$ increase in ISR. The increase in plasma glucose appears to partially reflect the predominance of non-rapid eye movement (REM) stages in early sleep. After sleep deprivation, plasma glucose levels were higher in the mid-morning to late afternoon despite similar insulin levels, suggesting decreased daytime insulin action. It turns out that the pattern of glucose secretion during nocturnal sleep deprivation differs significantly from the pattern during nocturnal sleep, and it is likely due in part to the absence of slow wave sleep and growth hormone secretion in the beginning of the night. Recent data suggest that optimizing sleep duration and quality should be tested as an intervention to improve glucose control in patients with type 2 diabetes.

\section{Diagnosing Sleep Related Breathing Disorders - An ENT perspective \\ Magne Tvinnereim, MD, Ph.D. \\ Specialist in ENT and Sleep Diseases. CEO EuroSleep and Spiromedical}

Sleep Related Breathing Disorders (SRBD) is a worldwide disease, occurring with an incidence on $15-20 \%$ in the adult population. Relating its pathophysiology mainly to the pharyngeal region, it is one of the most common diseasse in the ENT - discipline.

Initially there was focus on on obstructive Apneas and Hypopneas with increased Respiratory Effort (RE), the Obstrucive Sleep Apnea (OSA). Later on it has become evident that episodes without changed airflowand oxygendesauration- patterns but with increased RE and simultaneous Arousals may represent pathology as well. This entity is the Respiratory Effort Related Arousals (RERA) and is included in the terminology: $\mathrm{SRBD}=\mathrm{RERA}+$ OSA. The total amount of pathological episodes are, SRBD $=\mathrm{AHI}+\mathrm{RERA}$ 's $=\mathrm{RDI}$, where RDI is the Respiratory Distress Index.

In 2014, frequent comorbidities as hypertension and diabetes2 were included in the diagnosis.

SRBD represents a continuous disease, ranging from the relatively healthy habitual snorer, via the RERA to the severe OSA. The latter is treated with Continuous Positive Airway Pressure (CPAP) while different treatment modalities like surgery, implants, mandibular devices, positional trainers, etc. have to be considered regarding the milder forms. According to international standard (AASM) diagnosis has to be whole night recordings with monitoring of the RERA and OSA parameters.

In accordance with the new 2014 diagnosis upgrade and the actual parameters along with the statement of esophageal manometry being the gold standard for determination of RE, no available diagnostic system in the market hitherto perform a complete, correct and automatic SRBD diagnosis. 
The ApneaGraph Spiro is a new diagnostic system developed to include all the parameters needed. It is of particular interest to the ENT - doctors as it: 1) Gives a complete diagnoses with automatic, time consuming scoring, 2) Finds the light sufferers, which are more prone to surgery and early treatment, 3) Reliably determinates the RERAS as a combination of increased RE and simultaneous Arousals and 4) Gives the site of most prominent pharyngeal narrowing. The latter has a huge impact on selection of treatment type, especially regarding outcome of surgical treatment.

The ApneaGraph Spiro gives a clear indication of which type of treatment to choose. The diagnostic result along with the treatment options, including Surgery Phase I and II, will be discussed.

The important role as well as the huge market opportunity for the ENT - doctor is underlined.

\title{
Application of Medical Devices in the Treatment of Patients with Obstructive Sleep Apnea
}

\author{
Alexander Raynov, MD, PhD ${ }^{1}$ \\ Assoc. Prof. Mario Milkov, MD, PhD ${ }^{2}$ \\ ${ }^{1}$ Department of Otorhinolaryngology, University Hospital „Lozenetz“, Sofia \\ ${ }^{2}$ Faculty of Dental Medicine, Medical University Prof. „Paraskev Stoyanov“, Varna
}

The contemporary treatment of Obstructive Sleep Apnea (OSA) comprises two main directions - conservative and operative, each with strictly precised indications and contraindications. Among the conservative methods the Continuous Positive Airway Pressure (CPAP) therapy has become the golden standard in the treatment of patients with severe forms of OSA. Amid them, there are a significant number of patients who don't tolerate the regular usage of this equipment. For them and for the patients not suitable for surgical treatment, currently has been developed various devices and methods for conservative treatment - dental appliances, anti-snoring deviceses and etc., which will be discussed in the current presentation.

\section{Приложение на медицински изделия при лечението на пациенти с обструктивна сьнна апнея}

\author{
д-р Александър Райнов, д.м. ${ }^{1}$ \\ доц. д-р Марио Милков, д.м. ${ }^{2}$
}

${ }^{1}$ Катедра по оториноларингология, Университетска болница, „Лозенец“, София

${ }^{2}$ Катедра по дентална медицина, Медицински университет „Проф. Параскев Стоянов“, Варна

Съвременното лечение на обструктивната сънна апнея (ОСА) включва две основни направления - консервативно и оперативно, всяко от които със строго прецизирани показания и противопоказания. Сред методите за консервативното лечение като златен стандарт при лечението на пациентите с тежки форми на OCA се е наложила Continuous Positive Air Pressure (CPAP) терапията. При тези пациенти съществува немалка група хора, които не толерират употребата на тази апаратура. За тях, както и за пациентите, неподлежащи на оперативно лечение, понастоящем са разработени различни устройства и методи за консервативно лечение - зъбни протези, противохъркащи устройства и др., които ще бъдат разгледани в настоящата презентация. 


\title{
Modern High-tech Surgical Techniques for the Treatment of Obstructive Sleep Apnea
}

\author{
Zlatanov Hr., Yovcheva V., Georgieva N. \\ Department of Otorhinolaryngology - MMA - MHAT- Sofia, Bulgaria
}

Obstructive sleep apnea (OSA) is a potentially life-threatening condition and one of the most common causes of death worldwide.

Objective: Demonstration of our achievements in the treatment of patients with OSA varying in severity. Matherials and methods: We treated more than 300 patients with different severity if OSA. Part of them were outpatient and received radiofrequency thermoablation of soft palate and/or inferior turbinates. Other with more severe OSA were operated under general anesthesia - partial resection of uvula, resection and lifting of the palatine arches (uvulopalatoplasy) and tonsillectomy using ultrasound harmonic scalpel. In a third part of the patients the obstruction was caused by problems in the nasal breathing and they underwent a one-step operation under general anesthesia - septoplasty and radiofrequent thermoablation of the inferior turbinates.

Checkup examinations were performed on the tenth and thirtieth postoperative days.

Results: In more than $70 \%$ of the cases we observed improvement of the symptoms of OSA to an extent where no CPAP/BiPAP were needed. In the rest postoperativly the symptoms did not resolve, polysomnography did not show significant improvement and they were directed for CPAP/BiPAP. We resumed that additional factors for obstruction in these patients were overweight, impaired elasticity and tonus of the pharyngeal muscles, causing collapse of upper airways during sleep.

Conclusions: Radiofrequent thermoablation and ultrasound harmonic scalpel resection are modern, effective and safe methods for surgical treatment of patients with OSA. Applying them both in outpatient and in hospital gives excellent results with minimal invasiveness and minor costs for health facility.

Key words: Obstructive sleep apnea, radiofrequency thermoablation, uvulopalatoplasty, septoplasty, tonsillectomy, CPAP, BiPAP

\section{Съвременни високотехнологични хирургични техники за лечение на обструктивна сьнна апнея}

\author{
Златанов Хр., Йовчева В., Георгиева Н. \\ Клиника по оториноларингология - ВМА - София
}

Обструктивната сънна апнея (ОСA) е потенциално животозастрашаващо състояние и една от найчестите причини за смърт в световен мащаб.

Цел: Да демонстрираме нашите резултати, получени при лечението на болни, страдащи от сънна апнея с различна тежест.

Материал и методи: Лекувахме над 300 пациенти с изразена в различна степен сънна апнея, на част от които беше извършена високочестотна радиотермоаблация на меко небце и/или долни носни конхи в амбулаторни условия. На други с по-тежка обструкция под обща анестезия се извърши частична резекция на увула, резекция и повдигане на небни дъги (увулопалатопластика) и тонзилектомия с помощта на ултразвуков хармоничен скалпел. На трета част от пациентите, при които обструкцията беше за сметка на затруднено носно дишане, под обща анестезия се извърши едноетапно септопластика и радиочестотна термоаблация на долни носни конхи. Контролните прегледи се извършваха на десетия и тридесетия ден след оперативните намеси.

Резултати: В над 70\% от случаите се установи подобрение на симптомите на ОСА до такава степен, че да не се налага употребата на СРАР/ ВіРАР. При останалите постоперативно оплакванията персистираха, полимсомнографията също не показа значително подобрение и бяха насочени за СРАР/BiPAP. При тях се установи, че допълнителни фактори за обструкцията са наднормено тегло и нарушена еластичност и тонус на фарингеалната мускулатура, които предизвикват колапс при дишане по време на сън. 
Изводи: Високочестотната радиотермоаблация и ултразвуковата резекция са съвременни, ефективни и безопасни методи за хирургично лечение на ОСА. Прилагането им както в амбулаторни, така и в болнични условия дава отлични резултати при минимална инвазивност за пациентите и незначителни разходи за здравното заведение.

Ключови думи: обструктивна сънна апнея, радиочестотна термоаблация, увулопалатопластика, септопластика, тонзилектомия, СРАР/ВіРАР

\section{An Alternative of the „Pillar System’ in Selected Patients with Snoring and Mild Obstructive Sleep Apnea}

\section{R. Benchev, Sv. Vasileva}

The goal of the report is to share our results in the treatment of habitual snoring and mild forms of sleep apnea by implanting cartilages from the nasal septum in the soft palate.

The following methodology was used: in cases with nasal obstruction due to septal deviation and snoring, the cartilages left after the inferior and posterior chondrotomy were implanted into the soft palate. The idea for stabilization of the soft palate with autological cartilage was taken from The Pillar Procedure, where alogenic implants are inserted in the middle of the soft palate by special pistol. 27 patients from 27 to 64 years of age were operated upon. $70 \%$ of them were males.

The indications for surgery were set after endoscopic and functional assessment of the upper respiratory tract, Müller's test, questionnaires, visual-analogue scale /VAS/ and polysomnography PSG in patients suspected for obstructive sleep apnea.

The results of the surgical treatment were measured by functional assessment of nasal breathing and VAS. Subjective improvement of snoring was found in $82 \%$ and objective improvement of nasal breathing in $86 \%$ of the patients 6 month after the operation.

It is concluded that the described method could be used successfully in well selected patients.

\section{Diagnostic Characteristics in Pediatric Obstructive Sleep Apnea}

\section{Nikolova M', Rankov Kr' ${ }^{1}$, Raynov $\mathbf{A}^{\mathbf{2}}$}

${ }^{1}$ Department of Physiology and Biochemistry, National Sport Academy, Sofia

${ }^{2}$ Department of Otorhinolaryngology, University Hospital „Lozenetz“, Sofia

Introduction: Obstructive sleep apnea (OSA) is one of the most socially significant sleep disorders. In children, the diagnostic criteria for OSA, as well as part of the accompanying symptoms are different from those in adults. Usually the first meeting of the children suffering from OSA with medical specialist is in ENT office. Being aware of the problem OSA and prompt referral of the child to the Sleep laboratory for testing, the diagnosis is easy. Therapy, whether it be a surgical or by means of CPAP machine is also very effective. In most cases, however, the way the child to the sleep laboratory is long and painful, accompanied by an expensive and pointless research, misdiagnosed and unsuccessful treatments. This requires awareness of clinicians with some of the main manifestations of the pediatric OSA as well as the specific diagnostic features of this disease, in order to build up an effective diagnostic-therapeutic algorithm.

Methodology: For a period of one year in sleep laboratory were examined five children aged 6,7 $\pm 1,7 \mathrm{y}$. with suspected sleep breathing disorders. They were referred for sleep study by ENT specialist. Parents completed a a specifically developed questionnaire for sleep disorders for screening purposes and subsequently all children underwent full standard overnight polysomnography (PSG) by means of Miniscreen Pro equipment. 
Results: After the PSG all five children were diagnosed with OSA. Four of them, with the values of the indicators meet the criteria for diagnosis, even for adults. Measured diagnostic parameters were as follows: Apnea/ hypopnea index $(\mathrm{AHI})=22,46 \# / \mathrm{h}$. sleep $\pm 8,64$; Desaturation index $(\mathrm{DI})=19,74 \# / \mathrm{h}$. sleep $\pm 1,56$; Arousal index $(\mathrm{ArI})=16,44 \# / \mathrm{h}$. sleep $\pm 3,37$; Mean Desaturation (Mean Des.) $=89,60 \% \pm 2,06$; Sleep efficiency (SE) $=73,76 \% \pm 17,34$. Pearson correlation analysis showed high correlation coefficient $(\mathrm{r}=0,97)$ between percent of the positive parents answers of the questionnaires and AHI.

Conclusion: OSA Syndrome, which is characterized by severe desaturation during sleep leading to subsequent tissue hypoxia. Hypoxia is particularly fatal to developing organism, its physiological and neuropsychological development. The availability of easy and affordable screening method (questionnaire) would allow early detection of the syndrome in childhood.. The early detection and timely referral of children with OSA to specialized sleep laboratories as part of an unified diagnostic-therapeutic algorithm established nationwide, would be a huge contribution to adequate treatment of this disease in our country.

\title{
Диагностични особености на обструктивната сънна апнея в детска възраст
}

\author{
М. Николова ${ }^{1}$, Кр. Ранков ${ }^{1}$, Ал. Райнов ${ }^{2}$ \\ ${ }^{1}$ Катедра „Физиология и биохимия“, Национална спортна академия - София \\ ${ }^{2}$ Катедра по ушни, носни и гърлени болести, УБ „Лозенец“- София
}

Въведение: Обструктивната сънна апнея (OSA) е едно от най-значимите в социален аспект наруше-
ния на съня. При децата критериите за поставяне на диагнозата OSA, както и част от съпьтсващата
симптоматика са различни от тези при възрастните. Обикновено първата среща на децата, страдащи
от OSA, с лекар-специалист е в кабинета по УНГ. При познаване на проблема и своевременно насоч-
ване на детето за изследване към лаборатория по медицина на съня поставянето на диагнозата не е
проблем. Терапията, оперативна или посредством СРАР апарат, също е много ефективна. В повечето
случаи обаче пътят на детето до сънната лаборатория е дълъг и мъчителен, съпътстван от скъпи и без-
смислени изследвания, поставени грешни диагнози и неуспешни лечения. Това налага запознаване на
клиницистите с някои от основните проявления на ОСА в детска възраст и особености в диагности-
цирането на заболяването с цел изграждане на ефективен диагностично-терапевтичен алгоритъм.

Използвани методи: За една година в сънна лаборатория бяха изследвани пет деца на възраст $6,7 \pm 1,7$ год. Те бяха насочени за изследване на съня от оториноларинголог. Всички те преминаха скрининг чрез специално модифициран за целта въпросник за нарушения на съня, попълнен от родителите им, и последваща пълна полисомнографска регистрация с протокол „split-night“ посредством система Miniscreen Pro.

Резултати: След проведеното изследване и при петте деца се установи наличие на синдром на OSA. Четири от тях, по стойности на показателите, покриваха критериите за поставянето на диагнозата, дори и за възрастни. Отчетените диагностични показатели бяха както следва: апноично-хипопноичен индекс $(\mathrm{AHI})=22,46$ бр./час сън $\pm 8,64$; десатурационен индекс $(\mathrm{DI})=19,74$ бр./час сьн $\pm 1,56$; индекс на микросъбужданията $(\mathrm{ArI})=16,44$ бр./час сън $\pm 3,37$; средни нива на кислородна десатурация $($ Mean Des. $)=89,60 \% \pm 2,06$; ефективност на съня $(\mathrm{SE})=73,76 \% \pm 17,34$.

Коефициентът на корелация на Пиарсън показа голяма зависимост $(\mathrm{r}=0,97)$ между позитивните отговори на родителите от стандартния въпросник и основния диагностичен критерий - AHI.

Заключение: Синдромът на OSA, който се характеризира с тежки десатурации по време на сън, води до последваща тъканна хипоксия. Хипоксията е особено фатална за развиващия се детски организъм, за неговото физиологично и нервно-психично развитие. Наличието на лесен и достьпен скринингов метод (въпросник) би позволило ранното откриване на синдрома в детска възраст. Ранното откриване и своевременно насочване на децата с ОСА към специализираните лаборатории за изследване на съня, като част от един унифициран диагностично-терапевтичен алгоритъм, утвърден в национален мащаб, би имало огромен принос за адекватното лечение на това заболяване в нашата страна. 


\title{
Experience with Tonsillotomy for Sleep-disordered Breathing in Children
}

\author{
Sapundzhiev N, Genova P \\ Department of Otorhinolaryngology, Medical university - Varna
}

Objective: The purpose of this work is to review our experience with tonsillotomy and adenoidectomy (TT\&AT) in children with sleep disordered breathing (SDB).

Material and methods: Over a period of 5 years (06.2009-06.2014) a total of 34 children (21 boys, 13

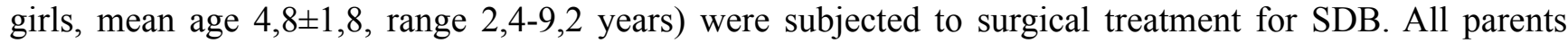
were informed on the surgical possibilities and TT\&AT were recommended. The interventions performed included 22x TT\&AT, 9x tonsillectomy (TE) \& AT and 3x AT only. Cold-steel surgical technique was used. Postoperative quality of sleep was evaluated based on feed-back from the parents.

Results: About $1 / 3$ of all parents rejected tonsillotomy alone, or after being consented by other medical specialists and opted for other intervention (TE\&AT, AT alone). In 4/22 (18\%) of the TT cases suturing was needed apart of bipolar cautery for stopping intraoperative bleeding. There were no cases of postoperative bleeding in all TT, TE and AT patients. TT\&AT and AT only children restored normal feeding the same day after the intervention, where as TE children experienced significant dysphagia over the next few days. On the control visit all parents reported satisfaction with the quality of sleep of their children. Only $1 / 22(4,5 \%)$ case of symptomatic recurrent tonsillar hyperplasia was observed.

Conclusion: TT as surgical technique appears to be not well known to the general public and medical specialists in Bulgaria. In conjunction with AT it appears to be very effective in controlling SDB. TT is relatively safe in terms of postoperative bleeding.

\section{Нашият опит с тонзилотомия при деца с нарушения на дишането по време на сьн}

\author{
Сапунджиев Н, Генова П \\ Клиника по УНГ-болести, Медицински университет - Варна
}

Цел: Целта на настоящото съобщение е да представи нашия опит с тонзилотомия и аденоидектомия (TT\&AT) при деца с нарушения на дишането по време на сън (НДПВС).

Материал и метод: За период от 5 години (06.2009-06.2014) 34 деца (21 момчета, 13 момичета, средна възраст 4,8 1,8 , интервал 2,4-9,2 години) бяха подложени на хирургично лечение по повод НДПВС. Във всички случаи родителите са били информирани за възможните хирургични техники и е била препорьчана ТT\&АТ. Извършените интервенции обхващат 22х TT\&AT, 9х тонзилектомия (TE) $\&$ AT и 3x AT само. Стандартно е прилагана класическа хирургична техника с режещи инструменти. Постоперативно качеството на съня е оценено на базата на информация от родителите на децата.

Резултати: При около $1 / 3$ от случаите родителите са отказали извършването на ТТ, вземайки това решение или сами, или след консултация с други медицински специалисти, и са избрали друг обем на хирургична интервенция (TE\&AT, само АТ). При 4/22 (18\%) от случаите с ТТ за овладяване на интраоперативното кървене освен биполярната каутеризация се е наложила хемостаза с прошивни лигатури. Не е наблюдавано постоперативно кървене при всичките пациенти с ТТ, ТЕ и АТ. Децата, подложени на TT\&AT и само на AT, са възстановили нормален прием на храна още в деня на операцията, докато децата, подложени на ТЕ, са имали значителна дисфагия с продължителност от няколко дни. При контролния преглед всички родители съобщават за значително подобрение на качеството на съня на децата им. Наблюдаван е само $1 / 22$ (4,5\%) случай на симптоматична повторна хипертрофия на тонзилите след ТТ.

Заключение: Хирургичната интервенция ТТ изглежда не е добре позната сред пациентите и медицинските специалисти в България и се приема резервирано. В комбинация с АT, ТT е ефективна за овладяване на НДПВС. ТТ е относително безопасна интервенция по отношение на постоперативното кървене. 


\title{
The Value of Drug-induced Sleep Endoscopy for the Treatment and Tailoring Surgery for Patients with Snoring and Obstructive Sleep Apnea
}

\author{
Itzhak Braverman MD \\ Otolaryngology Head and Neck Surgery Unit; Hillel Yaffe Medical Center. \\ Faculty of Medicine, Technion - Israel Institute of technology
}

Objective: Drug induced sleep endoscopy (DISE) is increasingly performed procedure, offering the possibility of dynamic upper airway evaluation during artificial sleep as a technique to select the proper surgical treatment for patients with obstructed sleep apnea (OSA).

Aim: To evaluate the value of DISE for tailoring the proper treatment of patients with snoring and OSA.

Methods: Retrospective, single surgeon, 43 patients, 6 women and 37 men (23-74 years), with snoring and obstructing sleep apnea, underwent DISE before deciding on the surgical treatment. DISE findings were reported using the NOHL and VOTE classifications systems; site, degree of airway narrowing and configuration of obstruction were reported. Patients underwent tailored surgery based on DISE findings included multi-level surgery; palate, tonsils, base of tongue and epiglottis.

Results: The obstruction and apnea was mainly at the velum $97.6 \%$, oropharynx $55.81 \%$, in combination with other structures, usually base of the tongue $65.11 \%$ and epiglottis $6.97 \%$.

After using DISE for patients with snoring and OSA, the surgical treatment that was tailored for the patients: CAUP- Coblation Upper Airway Procedure for palatal level with or without tonsillectomy, endoscopic base of tongue reduction with coblation, partial epiglottectomy. The results showed improvement of snoring and OSA severity in most of the patients. 14 patients completed secondary PSG around 6 months post operatively presenting 46\% average RDI improvement. Among this group 43\% (6 patients) had RDI below 10 $(\mathrm{p}<0.003)$. In a subgroup, super-responders (RDI change greater than 50\%), 9 patients achieved average RDI reduction of $71 \%$. Some patients pending post operative PSG, and few reported satisfactory outcome and declined secondary PSG.

Conclusions: DISE is a safe procedure, easily practicable, valid and reliable. We, therefore, consider it a fundamental clinical procedure that is essential before choosing the surgical treatment.

Our results suggest that a multilevel collapse, a complete collapse, and a tongue-base collapse are significantly associated with higher apnea hypopnea index values. Complete concentric collapse is more significantly associated with an increased body mass index but not always. We think that the weight did not play a significant role in the RDI reduction.

Our results show tailored surgery based on DISE may leverage sleep surgeries outcome significantly presenting $70 \%$ success rate based on our experience.

\section{Metabolic, Endocrine and Systemic Disorders Associated with the Syndrome of Obstructive Sleep Apnea (OSA)}

\author{
Vassileva Sv., Benchev R., Stoyanov S., Milkov M.
}

Sleep is a mandatory element of our live, but the knowledge of the reasons that make us fall asleep and processes occurring in the body during sleep were for a long time largely unclear. Only in recent decades become possible in-depth investigation of the processes occurring during sleep. In the 1930's with the advent of Electroencephalography started the study of brain activity during sleep. In the 1950's, distinct sleep stages and cycles were found and normal changes that occur in the functions of the nervous, cardio - vascular, endocrine and respiratory systems in each of these stages become clear. Opinions on the question: „Why do we sleep? „, were significantly changed and were accumulated evidence of changes in the body, occurring in peoples with not enough or inefficient sleep. The sleep is a normal state, in which are maintained a basic life functions, but the body rests. When the living organism is deprived of its requirements for sound sleep, the 
consequences are serious cognitive, cardiovascular, endocrine and metabolic disorders. OSA is a common disorder characterized by repeated episodes of obstruction of breathing (apnea and /or hypopnea) followed by transient desaturation of hemoglobin (hypoxemia) and arousals (awakenings), leading to fragmentation of the sleep.

So while it is now clear that OSA causes serious health consequences, the mechanisms are only now being researched in depth.

This presentation examines the currently available data on the mechanisms by which OSA increases the risk of obesity, hypertension, cardio - vascular diseases and type 2 diabetes in patients suffering from it.

\title{
Метаболитни, ендокринни и системни увреждания, свързани със синдрома на обструктивна сънна апнея (OSA)
}

\author{
Василева Св., Бенчев Р., Стоянов Ст., Милков М.
}

Сънят е задължителен елемент от живота ни, но познанията за причините, които ни карат да заспим, и процесите, настьпващи в организма по време на сън, дълго бяха в значителна степен неясни. Едва през последните няколко десетилетия стана възможно по-задълбоченото обследване на процесите, случващи се по време на сън. През 30-те години на 19. век, с появата на електроенцефалографията започна изучаването на мозъчната активност по време на сън. През 50-те години на миналия век бяха открити т. нар. фази и цикли на съня, както и нормалните изменения, които настъпват във функциите на нервната, сърдечносъдовата, ендокринната и дихателната системи във всяка от тези фази. Промениха се значително вижданията по въпроса: „Защо спим?“ и се натрупаха доказателства за промените в организма, настъпващи при недостатъчен и/или неефективен сън.

Сънят нормално е състояние, по време на което се поддържат основни жизнени функции, но тялото почива. Когато живият организъм е лишен от необходимото му количество пълноценен сън, последствията са сериозни когнитивни, сърдечносъдови, ендокринни и метаболитни разстройства. Синдромът на обструктивна сънна апнея (OSA) е често срещано заболяване, характеризиращо се с повтарящи се епизоди на механична обструкция на дишането (апнеи и хипопнеи), последвани от преходна десатурация на хемоглобина (хипоксемия) и араузали (пробуждания), водещи до фрагментация на съня.

И ако към днешна дата се приема като факт, че OSA е причина за сериозни негативни последици върху здравето, то механизмите за това едва сега се проучват в дълбочина. Настоящата презентация разглежда наличните към момента данни за механизмите, по които OSA повишава риска от затлъстяване, хипертония, сърдечносъдови заболявания и диабет тип 2 при страдащите от нея пациенти.

\section{Sedation for Endoscopic Procedures in Patients with Obstructive Sleep Apnea}

Nikoleta Slavova, Petja Ivanova, Maria Todorova, Viliyan Platikanov

Department of Anesthesiology, Emergency, Intensive and Marine medicine Medical University of Varna

Summary: Obstructive sleep apnea is a condition which results from an obstruction of the upper airway during sleep that occurs because of inadequate motor tone of the tongue and/or airway dilator muscles. According to statistic studies in the USA approximately $20 \%$ of adults may suffer from OSA, with nearly $7 \%$ exhibiting moderate-to-severe OSA. However, up to $93 \%$ of women and $82 \%$ of men with OSA are undiagnosed and thus untreated. These numbers are expected to increase with advancing age and obesity in the general population. 
Patients with OSA are at a higher risk of peri-procedure complications such as respiratory depression and decreased pharyngeal muscle tone, which may exacerbate airway obstruction, leading to hypoxia, hypercarbia, arrhythmias, and ultimately, cardiopulmonary arrest. Thus these patients present a particular challenge for the anesthetist, who should be acquainted with the associated medical comorbid conditions and plan accordingly to implement a safe course of action for the patient. This applies mainly for the ambulatory patients who are discharged to the home environment after the surgical procedure.

In this article we aim to explore the pathogenesis, systemic effects and relevance of OSA to anesthesia management, focusing on our experience with sedation for endoscopic procedures in patients with obstructive sleep apnea. We also intend to include the guidelines for pre-, intra- and postoperative management of these patients that have been developed and approved in our department.

\title{
Седация за ендоскопски процедури при пациенти с обструктивна сънна апнея
}

\author{
Николета Славова, Петя Иванова, Мария Тодорова, Вилиян Платиканов \\ Катедра по анестезиология, спешна, интензивна и морска медицина \\ Медицински университет - Варна
}

Резюме: Обструктивната сънна апнея (ОСА) е състояние, при което се наблюдава обструкция на горните дихателни пътища по време на сън в резултат на намален тонус на мускулатурата на езика и/или дилататорите на дихателните пътища. Според статистически данни от САЩ приблизително $20 \%$ от населението страда от ОСА, като при около 7\% се наблюдават клинични данни за умерена до тежка такава. До $82 \%$ от мъжете и $93 \%$ от жените с ОСА остават недиагностицирани и вследствие на това нелекувани. Очаква се също така със засилването на демографския проблем и затлъстяването на населението този процент да нарасне. При тези пациенти е налице повишен риск от потискане на дишането и намален тонус на фарингеалната мускулатура, които засилват обструкцията на дихателните пътища и водят до хипоксия, хиперкапнея, ритъмни нарушения и понякога до сърдечен арест. Ето защо анестезията е особено предизвикателство, а анестезиологът трябва да е запознат с асоциираните с ОСА усложнения и в съответствие с това да изгради и приложи възможно най-безопасния и оптимизиран план за действие. Това важи най-вече за пациентите за амбулаторни процедури, при които е недостатъчна постоперативното медицинско наблюдение.

В нашето изложение описваме рисковите фактори, патогенезата, системните ефекти и отношението на ОСА към анестезията, като се съсредоточим върху седация на пациенти с ОСА за ендоскопски процедури и представяме изградения и утвърден в нашата клиника протокол за действие в пред-, интра- и постоперативния период.

\section{General Anaesthesia and Obstuctive Sleep Apnea}

\author{
Atanas Zanev, Danail Lichev, Viliyan Platikanov \\ Dept for Anaesthesia, Emergency, Intensive and Marine Medicine \\ Medical University of Varna
}

\begin{abstract}
Summary: The syndrome of obstructive sleep apnea is an underrated anesthetic problem of social value, which in recent years has increased by a statistically significant rate. Still no definite clarity on the specific anesthetic techniques and monitoring, but the key ones has been some consensus. Clarification of anesthetic management in the perioperative period in patients with obstructive sleep apnea includes choice of anesthetic technique, airway management and monitoring. Obstructive sleep apnea is a direct negative risk factor for patients undergoing general anesthesia. An additional risk factor is often concomitant comorbidity - obesity,
\end{abstract}


arterial hypertension, cerebrovascular disease and diabetes. Poor management of perioperative anesthetic period is associated with increased intra- and postoperative mortality.

\title{
Обща анестезия и обструктивна сънна апнея
}

\author{
Атанас Занев, Данаил Личев, Вилиян Платиканов \\ Катедра по анестезиология, спешна, интензивна и морска медицина, \\ Медицински университет - Варна
}

Резюме: Синдромът на обструктивна сънна апнея е недооценен анестезиологичен проблем със социална значимост, която в последните години нараства със статистически значими темпове. Все още липсва категорична яснота по отношение на конкретните анестезиологични техники и мониторинг, но по отношение на ключовите такива е постигнат известен консенсус. Изясняването на анестезиологичното поведение в периоперативния период при пациентите с обструктивна сънна апнея включва избор на анестетична техника, управление на дихателния път и мониторинг. Обструктивната сънна апнея е директен отрицателен рисков фактор за пациентите, подложени на обща анестезия. Допълнителен рисков фактор е и често съпътстващият коморбидитет - обезитас, хипертония, мозъчно-съдова болест и диабет. Лошото анестезиологично управление на периоперативния период е свързано с повишена итра- и постоперативна смъртност.

\section{Adipocyte Physiology and Adipokines in Sleep Apnea Levent ÖZTÜRK ${ }^{1}$, Gülnur ÖZTÜRK ${ }^{2}$, Oktay KAYA ${ }^{1}$, Bengü Avcı ${ }^{1}$ \\ ${ }^{1}$ Department of Physiology, Trakya University Faculty of Medicine, Edirne TURKEY \\ ${ }^{2}$ Department of Physiotherapy and Rehabilitation, Trakya University Faculty of Health Sciences, Edirne, TURKEY}

Sleep apnea syndromes has emerged as a major public health problem because of its high prevalence amongst middle-aged, obese men as well as in lean individuals and women. Although sleep apnea has been mostly treated as a „local abnormality“ of the upper airways and respiratory tract, accumulating evidence underlines its systemic aspects. A number of associated features of OSA have led researchers to consider the possibility that sleep apnea is a manifestation of the metabolic syndrome i.e. dyslipidemia, dyscoagulation, hypertension and diabetes mellitus type 2 and their cardiovascular sequelae. Interestingly, it has been suggested that obesity's role in the genesis of sleep apnea is rather through its metabolic activity than a purely anatomic/mechanical impact. Human body comprises two types of adipose tissue namely brown and white adipose tissue (WAT). Brown adipose tissue is specialized for heat production by non-shivering thermogenesis whereas white adipose tissue serves as the main energy reservoir. However, understanding of the physiology of WAT changed over the past decade by definition of its secretory products which are collectively termed adipokines. Most of these adipocyte-derived secretory products were extensively studied in patients with sleep apnea syndrome. Experimental and observational data from human studies support the notion that sleep apnea is associated with altered circulating levels of adipokines. It is also well established that obesity is a leading pathophysiologic factor of sleep apnea. Impaired adipocyte physiology may be the pathophysiologic link between sleep apnea and its metabolic consequences. Furthermore, it may be the common pathophysiologic mechanism that results in both sleep apnea and metabolic syndrome. 


\title{
Sleep Apnea in Children with Obesity
}

\author{
Ch. Madjova, M. Milkov, Vl. Panov \\ Dental Faculty, Medical University of Varna
}

Objectives: A lot of studies have uncovered that significant morbidity can be associated with a wide range of undiagnosed obstructive sleep apnea cases. Overweight and obesity are potentially modifiable risk factors.

Aim: To make analysis of scientific articles concerning frequency, characteristics and pathological changes of the upper airways in children with sleep apnea and obesity.

Design: A literature review for a period of 15 years.

Results: The relation between obesity and sleep-disordered breathing is known since the 1800s when Charles Dickens wrote about it in „The Posthumous Papers of the Pickwick Club“ describing one ,fat boy“ named Joe who has a sleep problem. The prevalence of childhood obesity is increasing every year in all countries and the frequency of sleep-disorders is growing up respectively. Reviewed studies demonstrated that obesity is an important risk factor for obstructive sleep apnea. The obese subjects with sleep apnea have enlarged soft tissue structures around the upper airway, increased size of the tongue, soft palate and lateral pharyngeal walls and deposits of fat of the posterior and lateral oropharyngeal airspace at the level of the soft palate.

Conclusion: Studies proved that increased level of fat in obese children raise the risk for obstructive sleep apnea and this important health problem is often neglected by doctors and their parents.

Key words: sleep apnea, obesity in children

\section{Сънна апнея при деца сьс затльстяване}

\author{
Х. Маджова, М. Милков, Вл. Панов \\ Факултет по дентална медицина, Медицински университет - Варна
}

Резюме: Много изследвания разкриват, че значителна заболеваемост може да бъде свързана с широк спектър от недиагностицирани случаи на обструктивна сънна апнея. Наднорменото тегло и затлъстяването са потенциално променливите рискови фактори.

Цел: Да се направи анализ на научни статии, свързани с честотата, характеристиките и патологичните промени на горните дихателни пътища при деца със сънна апнея и затлъстяване.

Дизайн: Литературен обзор за период от 15 години.

Резултати: Връзката между затлъстяването и обструктивна сънна апнея е познато още от 1800 г., когато Чарлз Дикенс е написал за това в „Посмъртните записки на клуба „Пикуик“, описвайки едно дебело момче на име Джо, което има проблем със съня. Разпространението на затлъстяването в детска възраст се увеличава всяка година година във всички страни и честотата на нарушенията на съня расте респективно. Проучените изследвания показват, че затлъстяването е важен рисков фактор за обструктивна сънна апнея. Затлъстелите хора със сънна апнея имат уголемени меки тъкани около горните дихателни пътища, увеличен размер на езика, мекото небце и латералните стени на фаринкса и мастни депа на задното и страничното орофарингеално въздушно пространство на нивото на мекото небце.

Заключение: Проучванията доказват, че увеличаването на мазнините при затлъстелите деца повишава риска от обструктивна сънна апнея и този важен здравен проблем често се пренебрегва от лекарите и техните родители.

Ключови думи: сънна апнея, деца със затльстяване 


\title{
Интраорални средства за лечение на хъркането
}

\author{
Ж. Баташка ${ }^{1}$, Д. Вичева ${ }^{2}$, А. Бататашки ${ }^{3}$ \\ ${ }^{1}$ Медицински колеж - Пловдив, специалност „Зъботехник“ \\ ${ }^{2}$ Медицински университет - Пловдив, Катедра „Уши, нос, гърло“ \\ ${ }^{3}$ Медицински университет - Пловдив, катедра „Специална хирургия“
}

Резюме: Затрудненото свободно преминаване на въздуха през носа или гърлото води до вибрации на отпуснатите по време на дълбоката фаза на сьня меки тъкани, намиращи се в дисталната част на гърлото, и до издаване на характерен шум, по-известен като хъркане. Пониженият мускулен тонус по време на сън, често съпроводен със спане по гръб, води до отпускане на долната челюст назад, а оттам и на корена на езика към мекото небце, което води до стесняване на фарингеалното пространство и до необходимост нужният обем въздух да се вдиша с по-висока скорост.

$\mathrm{C}$ прилагането на интраоралните средства за лечение на хъркането се цели да се освободи фарингеалното пространство и да се освободи свободното преминаване на вдишания въздух. Такива интраорални средства са силиконовите шини, небните импланти и различните ортодонтски приспособления за фиксиране на долната челюст в предна позиция.

Ключови думи: интраорални средства, лечение, хъркане

\section{Entrepreneurship Business in the Field of Diagnosis and Management of Obstructive Sleep Apnea}

\author{
A. Mirchev, M. Milkov ${ }^{1}$, P. Nedev ${ }^{1}$, Ts. Tonchev ${ }^{1}$, D. Vicheva ${ }^{2}$, R. Benchev ${ }^{3}$, \\ L. Matev ${ }^{1}$, H. Madjova ${ }^{1}$, S. Vasileva ${ }^{1}$, K. Nogalchev ${ }^{1}$, G. Iliev ${ }^{1}$ \\ University „Professor Asen Zlatarov“ of Bourgas, \\ ${ }^{1}$ Medical University „Prof. Paraskev Stoyanov“ of Varna, \\ ${ }^{2}$ Medical University of Plovdiv and \\ ${ }^{3}$ Hospital of the Ministry of the Interior of Sofia
}

\begin{abstract}
In the scientific communication, the approach to the diagnosis and treatment of sleep apnea as an entrepreneurship business activity was substantiated. For that purpose, the essence of the entrepreneurship activity as well as its specific peculiarities in the area of public health was considered. The characteristics of the specialists in the field of sleep apnea acting as entrepreneurs and managers of an innovative 'start-up' health institution were revealed. The results from the present investigation will contribute to the enhancement of the quality and effectiveness of medical services related to the tailored diagnosis and complex treatment of the patients with sleep apnea and as a whole - to the solution of this health problem of rising medico-social significance.
\end{abstract}

Key words: sleep apnea, diagnosis, treatment, entrepreneurship, business, management, 'start-up' health institution 


\title{
Бизнесьт в областта на диагностиката и лечението на сьнната апнея като предприемаческа дейност
}

\author{
А. Мирчев, М. Милков ${ }^{1}$, П. Недев ${ }^{1}$, Ц. Тончев ${ }^{1}$, Д. Вичева ${ }^{2}$, Р. Бенчев ${ }^{3}$, \\ Л. Матев ${ }^{1}$, Х. Маджова ${ }^{1}$, С. Василева ${ }^{1}$, К. Ногалчев ${ }^{1}$, Г. Илиев ${ }^{1}$ \\ Университет „Проф. д-р Асен Златаров“ - Бургас, \\ ${ }^{1}$ Медицински университет „Проф. д-р Параскев Стоянов“- Варна \\ ${ }^{2}$ Медицински университет - Пловдив \\ ${ }^{3}$ Болница на МBP - София
}

Резюме: В научното съобщение се обосновава подходът към диагностиката и лечението на сънната апнея като предприемаческа бизнес дейност. За тази цел се обсьждат както същността на предприемаческата дейност, така и нейните специфични особености в сферата на здравеопазването. Разкриват се характеристиките на специалистите в областта на сънната апнея като предприемачи и мениджъри на иновативно „start-up“ здравно заведение. Резултатите от настоящото изследване ще съдействат за повишаване на качеството и ефективността на здравните услуги, свързани с индивидуализираната диагностика и комплексното лечение на болните със сънна апнея, и като цяло - за решаването на този здравен проблем с нарастващо медико-социално значение.

Ключови думи: сънна апнея, диагностика, лечение, предприемаческа дейност, бизнес, мениджмънт, „start-up“ здравно заведение

\section{Improving the Acoustics in the Oral Cavity of Musicians who Play wind Instruments Подпомагане и облекчаване на мускулното напрежение на работата на устните по време на свирене на дврвени духови инструменти

\author{
Kamen Nogalchev ${ }^{1}$, Mario Milkov ${ }^{1}$, Sava Dimitrov $^{2}$, Dessislava Konstantinova ${ }^{1}$ \\ ${ }^{1}$ Prof. Paraskev Stoyanov Medical University of Varna Faculty of Dental Medicine \\ ${ }^{2}$ National Academy of Music „Prof. Pantcho Vladigerov“
}

Background: Dentists are often asked by patients and their parents how can they improve the acoustics in the oral cavity. Indeed, amongst wind instrument players and teachers it has been popular belief that playing a wind instrument leads to malocclusion.

Aim: To investigate the effects of playing a wind instrument with silicone grind on the acoustic in the oral cavity.

Material and Methods: This was a cross-sectional observational study. The subjects were subdivided according to the type of instrument mouthpiece.

Results, Conclusions: Using the teeth as a foundation we help to relieve the muscle tension, the direct contact of the lips and teeth. Using the grind we increase the surface area onto which the lip rests thus we avoid cuts on the bottom lip. The contact is on a large surface area rather than directly onto the cutting edge of the lower central incisors creating a state of more intense and longer playing, the lip becomes more resistant, the muscle is not at its maximum tone and there is no chronic pain (constant trauma of the lower lip is missing).

Key words: wind instruments, acoustics, soft tissue, occlusion 


\title{
ApneaGraph System
}

\author{
L. Matev, M. Milkov, Z. Tonchev, P. Nedev, A. Pomakova \\ Medical University „Prof. Paraskev Stoyanov“ of Varna
}

A transnasal soft probe with $1.9 \mathrm{~mm}$ thickness is being positioned in the upper esophagus of the patients. Data is recorded in a data logger, which is attached to a belt and placed in front of the chest. The probe has two thermistors for measuring the air flow, namely one in the nasopharynx (T1) and one in the oropharynx (T0) over the entrance to the larynx. Furthermore, there are two pressure sensors, one just below the soft palate (P2) and one in the upper esophagus in the area of transition between the upper and middle third of the esophagus (P0). In order to secure the correct position of the catheter there is also a reference mark $(\mathrm{K})$ just below the palate. The measurement time is 6 hours.

The data is recorded on a conventional cardiorespiratory polygraphy. The internal measurement of airways and airflow pressure with the probe eliminates the need to wear external nasal devices for measuring the airflow, such as thoracic and abdominal belts. Pressure sensors measure pressure just below the soft palate and the pressure of the esophagus.

Due to the presence of two internal pressure measurements there could be recorded two gradients, referring to the pressure in the area, namely one - between the pressure in the area and that one directly below the velum palatinum (P2) and the second - between $\mathrm{P} 2$ and esophageal pressure (P0). Based on these two pressure gradients the collapse of the upper airway can be classified to „upper“, resp. „lower“ obstruction. The system does not allow any further differentiation.

\section{Apnea Graph AG-200 - нови хоризонти при диагностиката на сънната апнея}

\author{
Л. Матев, М. Милков, Ц. Тончев, П. Недев, А. Помакова \\ Медицински университет „Проф. д-р Параскев Стоянов“- Варна
}

На пациентите се въвежда трансназално мека сонда с дебелина 1,9 мм до горния езофагус. Данните се записват в логер, който се прикрепва към колани и се поставя пред гърдите. Сондата има два термистора за измерване на въздушния поток, а именно един в назофаринкса (Т1) и един в орофаринкса (T0) над входа на ларинкса. Освен това има два сензора за налягане, един точно под мекото небце (Р2) и един в горния езофагус в областта на прехода между горната и средна трета на хранопровода (Р0). С цел подсигуряване на коректното положение на катетъра точно под небцето се намира и една контролна маркировка (К). Времето на измерване е 6 часа.

Регистрират се данните на една конвенционална кардиореспираторна полиграфия. Поради вътрешната регистрация на натиска на дихателните пьтища и дихателния поток чрез сондата отпада носенето на външни назални апарати за измерване на потока като гръдни и коремни колани. Сензорите за налягане измерват налягането точно под платното на мекото небце и налягането на езофагуса.

Поради наличието на две вътрешни измервания на налягането биха могли да бъдат регистрирани два градиента, позовавайки се на налягането в областта, а именно един - между налягането в областта и този точно под velum palatinum (Р2) и втори - между Р2 и езофагеалното налягане (Р0). На основата на тези два градиента на налягане колапсът на горните дихателни пътища може да бъде причислен към „горна“, респ. „долна““ обструкция. Системата не позволява по-нататъшна диференциация. 


\title{
Anterior Palatoplasty - Why, Whom, How \\ Mustafa Kemal ADALI
}

Obstructive sleep apnea (OSA) is a common disorder which is characterized by the collapse of the pharyngeal airway. The most common site of obstruction in OSA is the retropalatal region. Many surgical techniques have been introduced to solve the problem on this site. Anterior palatoplasty is one of the techniques which aims to solve the collapse on retropalatal space.

The surgery is performed under the general anesthesia. A horizontal rectangular strip of mucosa is removed from the soft palate,down to the muscle layer. The horizontal stripped area on the soft palate was sutured with an absorbable material and the entire soft palate was transposed anteriorly and superiorly.

The technique has good post surgical outcomes in appropriate cases, according to our experience and literature. The preoperative evaluation and selection of appropriate patients for the technique have critical importance.

\section{Sleep-related Breathing Disorders}

\author{
M. Milanova \\ University Hospital „St. Naum“ - Sofia, Medical University
}

The International Classification of Sleep Disorders-2 (ICSD-2 -2005, currently undergoing revision), combines a symptomatic presentation (insomnias) with pathophysiology (circadian rhythms) and in part a body systems (breathing disorders). Disordered ventilation during sleep is primary dived into obstructive and central syndromes (tabl. 1).

Table 1. Sleep-related Breathing Disorders - Classification

\begin{tabular}{|l|c|}
\hline Sleep-Related Breathing Disorders: ICSD-2 and ICD-10 & G47.31 \\
\hline Primary central sleep apnea & $\mathrm{R} 06.3$ \\
\hline Central sleep apnea due to Cheyne-Stokes breathing pattern & $\mathrm{G} 47.32$ \\
\hline Central sleep apnea due to high altitude periodic breathing & $\mathrm{G} 47.31$ \\
\hline Central sleep apnea due to a medical condition, not Cheyne-Stokes & $\mathrm{F} 10-19$ \\
\hline Central sleep apnea due to a drug or substance & $\mathrm{P} 28.3$ \\
\hline Primary sleep apnea of infancy & $\mathrm{G} 47.33$ \\
\hline Obstructive sleep apnea, adult & $\mathrm{G} 47.33$ \\
\hline Obstructive sleep apnea, pediatric & $\mathrm{G} 47.34$ \\
\hline Sleep-related nonobstructive alveolar hypoventilation, idiopathic & $\mathrm{G} 47.35$ \\
\hline Congenital central alveolar hypoventilation syndrome & $\mathrm{G} 47.36$ \\
\hline $\begin{array}{l}\text { Sleep-related hypoventilation/hypoxemia due to pulmonary parenchymal or } \\
\text { vascular pathology }\end{array}$ & $\mathrm{G} 47.36$ \\
\hline Sleep-related hypoventilation/hypoxemia due to lower airways obstruction & $\mathrm{G} 47.36$ \\
\hline $\begin{array}{l}\text { Sleep-related hypoventilation/hypoxemia due to neuromuscular or chest wall } \\
\text { disorders }\end{array}$ & $\mathrm{G} 47.30$ \\
\hline Sleep apnea/sleep related breathing disorder, unspecified & \\
\hline
\end{tabular}

Central apnea syndromes (1) include those in which respiratory effort is diminished as a result of central nervous system dysfunction. Other central sleep apnea (CSA) forms are associated with underlying pathologic or environmental causes, such as Cheyne-Stokes breathing pattern (2) or high-altitude periodic breathing (3). Primary central sleep apnea is a disorder of unknown cause characterized by recurrent episodes of cessation of breathing during sleep without associated ventilatory effort in a non hypercapnic patient. This 
diagnosis requires that 5 or more apneas per hour of sleep are recorded by polysomnography. CSA due to Cheyne-Stokes breathing (CSB) pattern is characterized by recurrent apneas (hypopneas) alternating with prolonged hyperventilation periods in a crescendo-decrescendo pattern. This pattern is characteristically seen in non-rapid eye movement sleep. CSB is typically seen in medical disorders, such as heart failure and cerebrovascular disorders. CSA due to high-altitude is characterized by sleep disturbance that is caused by cycling periods of apnea and hyperpnea. Primary sleep apnea of infancy is a disorder of respiratory control most often seen in preterm infants, but it can occur also in other predisposed infants (4). This may be a developmental pattern, or it may be secondary to other medical disorders.

The obstructive sleep apnea syndromes include those in which there is an obstruction in the airway resulting in increased breathing effort. Upper airway resistance syndrome has been recognized as a manifestation of obstructive sleep apnea syndrome (OSA). OSA in adults is characterized by repetitive episodes of cessation of breathing (apneas) or partial upper airway obstruction (hypopneas) $(5,6)$. Snoring and sleep disruption are typical. Excessive daytime sleepiness or insomnia can result. Five or more respiratory events per hour of sleep in the presence of daytime sleepiness are required for diagnosis. Increased respiratory effort occurs during the respiratory event. OSA in pediatrics is characterized by features similar to those seen in the adult, but cortical arousals may not occur, possibly because of a higher arousal threshold (7).

Sleep-related hypoventilation syndromes comprise 5 disorders associated with hypoventilation or hypoxemia during sleep. Idiopathic sleep-related alveolar hypoventilation refers to decreased alveolar ventilation resulting in sleep-related arterial oxygen desaturation in patients with normal mechanical properties of the lungs (8). Congenital central alveolar hypoventilation is a failure of automatic central control of breathing in infants $(9,10)$. Sleep-related hypoventilation due to a medical condition is a subgroup of disorders of impaired lung function or chest wall mechanics. Sleep-related hypoventilation related to pulmonary parenchymal or vascular pathology is due to interstitial lung disease (11). Sleep-related hypoventilation due to lower airway obstruction is seen in patients with lower airway disease, such as chronic obstructive lung disease and emphysema (12). Sleep-related hypoventilation due to neuromuscular and chest wall disorders is seen in neuromuscular disease or kyphoscoliosis (13). The neurological assessment of central sleep disordered breathing includes the afferent, integrative (central nervous system) and efferent part of the breathing regulation.

\title{
Нарушения на дишането по време на сьн
}

\author{
М. Миланова \\ МБАЛНП „Свети Наум“ - София
}

Международната класификация на разстройствата на съня (ICSD 2, издадена 2005 г., ревизирана в момента) използва симптоматично (инсомнии), патофизиологично (нарушения в циркадианния ритъм) и системно (нарушения на дишането) представяне на заболяванията. Нарушенията на дишането по време на сън принципно се подразделят на обструктивни и централни синдроми (табл. 1).

Таблица 1. Класификация на нарушенията на дишането по време на сън

\begin{tabular}{|l|c|}
\hline \multicolumn{2}{|l|}{ Нарушения на дишането по време на сън: Международна класификация на разстройствата на } \\
съня-2 и МКБ-10 & $\mathrm{G} 47.31$ \\
\hline Пьрвична ЦСА & $\mathrm{R} 06.3$ \\
\hline ЦСА поради дишане тип Cheyne-Stokes & $\mathrm{G} 47.32$ \\
\hline ЦСА поради големи надморски височини & $\mathrm{G} 47.31$ \\
\hline ЦСА при вътрешни заболявания, не тип Сheyne-Stokes & $\mathrm{F} 10-19$ \\
\hline ЦСА поради злоупотреба с медикаменти и субстанции & $\mathrm{P} 28.3$ \\
\hline Пьрвична сънна апнея при деца & $\mathrm{G} 47.33$ \\
\hline ОСА при възрастни & $\mathrm{G} 47.33$ \\
\hline ОСА при деца & $\mathrm{G} 47.34$ \\
\hline Свързаната със съня необструктивна алвеоларна хиповентилация, идиопатична
\end{tabular}




\begin{tabular}{|l|c|}
\hline Синдром на конгенитална централна алвеоларна хиповентилация & $\mathrm{G} 47.35$ \\
\hline $\begin{array}{l}\text { Свързаната със съня хиповентилация/хипоксемия при паренхимна белодробна } \\
\text { и съдова патология }\end{array}$ & $\mathrm{G} 47.36$ \\
\hline $\begin{array}{l}\text { Свързаната със съня хиповентилация/хипоксемия при обструкция на долните } \\
\text { дихателни пътища }\end{array}$ & $\mathrm{G} 47.36$ \\
\hline $\begin{array}{l}\text { Свързаната със съня хиповентилация/хипоксемия при невромускулни и забо- } \\
\text { лявания на гръдната стена }\end{array}$ & $\mathrm{G} 47.36$ \\
\hline Сънна апнея/нарушение на дишането по време на сън, неуточнени & $\mathrm{G} 47.30$ \\
\hline
\end{tabular}

Централната сънна апнея (1) включва синдроми, при които има намалено дихателно усилие вследствие на дисфункция на централната нервна система. Други форми на централна сънна апнея (ЦСА) са свързани с патологични причини или промени в обкръжаващата среда като дишане тип СheyneStokes (2) или периодично дишане на големи височини (3). Пьрвичната ЦСА е заболяване с неясни причини, което се характеризира с повтарящи се епизоди на прекъсване на дишането по време на сън при отсъствие на дихателно усилие и хиперкапнея. Диагнозата изисква 5 или повече апнеи на час сън, записани полисомнографски. ЦСА поради дишане тип Cheyne-Stokes (CSB) ce характеризира с повтарящи се апнеи (хипопнеи), които се редуват с периоди на хипервентилация от кресчендо-декресчендо вид. Среща се предимно по време на ортодоксалния сън. Дишането тип Cheyne-Stokes ce среща най-често при сърдечна недостатъчност и мозъчно-съдови заболявания. Дишането тип Cheyne-Stokes поради голяма надморска височина се характеризира с циклични периоди на апнея и хиперпнея. Първичната ЦСА при деца е заболяване на респираторния контрол най-вече при недоносени, но може да се наблюдава и при други предразположения (4). Тя може да се дължи на незрялост на регулацията или на други вътрешни заболявания.

Синдромите на обструктивна апнея се характеризират с обструкция на дихателните пътища, която води до повишено дихателно усилие. Повишеното съпротивление в дихателните пътища се счита за степен в развитието на обструктивната апнея. Обструктивната сънна апнея (OCA) при възрастни се характеризира с повтарящи се епизоди на прекъсване на дишането (апнеи) или частична обструкция на дихателните пътища (хипопнеи) $(5,6)$. Хъркането и фрагментацията на съня са типични симптоми на апнеята. Ексцесивната дневна сънливост е друг характерен симптом. За поставяне на диагнозата са необходими 5 или повече дихателни събития при наличие на дневна сънливост. По време на дихателното събитие се регистрира повишаващо се дихателно усилие. ОСА при педиатричните пациенти се отличава по липсата на кортикално събуждане по време на полисомнография, най-вероятно поради повишения праг на събуждане (7).

Хиповентилационните синдроми по време на сън се подразделят на 5 заболявания протичащи с хиповентилация и хипоксемия. Идиопатичната алвеоларна хиповентилация по време, на сън представлява намалена алвеоларна вентилация, която води до кислородна десатурация при пациенти с нормални механични свойства на белия дроб (8). Конгениталната централна хиповентилация е нарушение на автоматичния централен контрол на дишането при деца $(9,10)$. Свързаната със съня хиповентилация при вътрешни заболявания е асоциирана с нарушения в белодробната функция или гръдната стена, например интерстициални промени при белодробни паренхимни и съдови заболявания (11). Свързаната със съня хиповентилация при обструкция на долните дихателни пътища се среща при пациенти с емфизем и ХОББ (12). Свързаната със съня хиповентилация при нарушение на невромускулното предаване и заболявания на гръдната клетка се среща при кифосколиоза и невромускулни болести (13). Неврологичната класификация на ЦСА и хиповентилационните синдроми включва нарушения на дишането поради засягане на аферентната, интегративната (централна нервна система) и еферентната част на регулаторната система на дишането. 


\title{
Clinical Study of Masticatory Function of Patients with Fixed and Removable Prostheses
}

\author{
D. Konstantinova, M. Dimova, M. Milkov
}

Prof. Paraskev Stoyanov Medical University of Varna, Faculty of Dental Medicine

Introduction: A thorough dental prosthetic treatment must meet all three medico-biological criteria. Dental aesthetics becomes worthless if dentures do not meet the functional requirements. Therefore, the study of masticatory efficiency proves essential in the evaluation of dental prosthetic treatment.

Aim: The authors set themselves the goal to investigate objectively and subjectively the masticatory function after the recovery of the masticatory unit with various types of fixed and removable prostheses.

Materials and methods: Subject of the study are 38 patients with prostheses as follows: 12 with fixed prostheses, 12 with partial-removable prostheses and 14 with dentures. Objective study is based on sieve analysis test food of natural material. The subjective survey is done through a survey of 15 questions.

Results: The results report almost fully restored function in patients with fixed prostheses (91\%), a lower recovery rate in the patients with removable prostheses $(74 \%)$ and the lowest in patients with dentures $(57 \%)$.

Conclusion: The main objective of prosthetic treatment is to fulfil of the three medico-biological criteria. This obligate the dentist to take into account studying the masticatory function after each conducted prosthetic treatment.

\section{Клинично изследване на дъвкателната функция при пациенти, протезирани с неподвижни и подвижни конструкции}

\author{
Д. Константинова, М. Димова, М. Милков \\ Медицински университет „Проф. д-р Параскев Стоянов“ - Варна, \\ Факултет по дентална медицина
}

Увод: Пълноценното протетично лечение трябва да удовлетворява и трите медико-биологични показателя. Ако конструкциите не отговарят на функционалните изисквания, оптималното възстановяване на естетика е неосъществимо и резултатите от лечението са ненадеждни и краткотрайни.

Цел: Авторите си поставиха за цел да изследват обективно и субективно дъвкателната функция след възстановяване на дъвкателния апарат с различни видове неподвижни и подвижни протезни конструкции.

Материали и методика: Материал на изследването са 38 пациенти, протезирани както следва: 12 с неподвижни конструкции, 12 с частични подвижни протези и 14 с цели протези. Обективното изследване се базира на ситов анализ на сдъвкана тестова хапка от естествена суровина. Субективното изследване се осъществи чрез анкета с 15 въпроса.

Резултати: Получените резултати отчитат най-пълноценно възстановена функция при пациентите с неподвижни конструкции (91\%), по-малка степен на възстановяване при частични подвижни протези (74\%) и най-слаба - при цели протези (57\%).

Заключение: Основна цел на протетичното лечение е удоволетворяването на трите медико-биологични критерии - профилактичен, функционален и естетичен. Това поставя пред лекаря по дентална медицина като неотменна задача изследването на дъвкателната функция след всяко проведено протетично лечение. 


\title{
Functional Disorders of Patients with Dentomaxillary Deformities and Removable Dental Prostheses
}

\author{
D. Konstantinova, H. Arnautska, M. Dimova, M. Milkov \\ Prof. Paraskev Stoyanov Medical University of Varna, Faculty of Dental Medicine
}

Normal function requires the coordinated action of many elements, including teeth, salivary glands, tongue, and masticatory muscles. Dysfunction in any of these areas can result in impaired masticatory and vocal function. Missing teeth are a concern to the patient and restorative dentist, and this can be a multifactorial problem that involves esthetics, phonetics, mastication and swallowing. Few studies dealt with the influence of occlusal conditions on the masticatory and vocal function. Based on reviews of research data the authors of the present study attempt to analyze the masticatory and vocal disfuncton in patients with occlusal anomalies and removable dentures. Conclusions: From the available literature, it appears that a subject whose malocclusion is severe enough to require orthodontic treatment or edentuoluos with removable prostheses have disfunctions in masticatory apparatus than one with no need for orthodontic and prosthetic treatment. Hence, in addition to esthetic considerations, improving the patient's chewing function by improving occlusal relationships could be an indication for dental treatment. The perceptive integration of interspecialty orthodontic and otolaryngologic treatment before restorative dentistry can obviate deleterious circumstances that threaten successful completion of the treatment plan.

\section{Функционални нарушения при пациенти със зъбно-челюстни деформации и подвижни протезни конструкции}

\author{
Д. Константинова, Х. Арнаутска, М. Димова, М. Милков \\ Медицински университет „Проф. д-р Параскев Стоянов“ - Варна, \\ Факултет по дентална медицина
}

Нормалната функция на дъвкателния апарат изисква координация между много структури, включващи зъби, слюнчени жлези, език, дъвкателни мускули. Нарушенията в някои от тези органи може да доведат до ограничаване на дъвкателната и говорна функция. Липсващите зъби и нарушеното оклузоарикулационно равновесие са мултикаузален проблем, който включва естетика, фонетика, дъвкане, гълтане. Малко изследвания отчитат влиянието на оклузалните съотношения върху дъвкателната и говорна функция. На база на литературни данни авторите на настоящото проучване правят опит да анализират нарушенията на дъвкателната и говорна функция при пациенти с оклузални аномалии и подвижни протези. Заключения: От литературния обзор се констатира, че пациент с малоклузия, изискваща ортодонтско лечение, или обеззъбен пациент с подвижна протеза имат различно изразени функционални нарушения в сравнение с такива, които нямат нужда от съответното лечение. От тук следва, че показание за лечение е необходимостта от възстановяване на дъвкателната и говорна функция на пациента чрез коригиране на оклузо-артикулатионното равновесие, а също и на естетичните фактори. Интердисциплинарният подход между ортодонти, оториноларингисти и протезисти може да улесни успешното изпълнение на лечебния план. 